\title{
Effects of partially replacing dietary corn with molasses, condensed whey permeate, or treated condensed whey permeate on ruminal microbial fermentation
}

\author{
A. D. Ravelo, ${ }^{1}$ B. Calvo Agustinho, ${ }^{1 *}$ J. Arce-Cordero, ${ }^{1}$ H. F. Monterio, ${ }^{1}$ S. L. Bennet, ${ }^{1} \dagger$ E. Sarmikasoglou, ${ }^{1}$ \\ J. Vinyard, ${ }^{1}$ E. R. Q. Vieira, ${ }^{1} \ddagger$ R. R. Lobo, ${ }^{1}$ L. F. Ferraretto, ${ }^{2}$ D. Vyas, ${ }^{1}$ and A. Faciola ${ }^{1} \S$ \\ ${ }^{1}$ Department of Animal Sciences, University of Florida, Gainesville 32611 \\ ${ }^{2}$ Department of Animal and Dairy Sciences, University of Wisconsin-Madison, Madison 53706
}

\begin{abstract}
Corn is a feedstuff commonly fed to dairy cows as a source of energy. The objective of this study was to evaluate whether partially replacing dietary corn with molasses or condensed whey permeate, in lactating dairy cow diets in a dual-flow continuous culture system, can maintain nutrient digestibility by ruminal microorganisms. Furthermore, this study evaluated whether treating condensed whey permeate before feeding could aid the fermentation of the condensed whey permeate in the rumen. Eight fermentors were used in a $4 \times 4$ replicated Latin square with 4 periods of $10 \mathrm{~d}$ each. The control diet $(\mathrm{CON})$ was formulated with corn grain, and the other diets were formulated by replacing corn grain with either sugarcane molasses (MOL), condensed whey permeate (CWP), or treated condensed whey permeate (TCWP). Diets were formulated by replacing $4 \%$ of the diet dry matter (DM) in the form of starch from corn with sugars from the byproducts. Sugars were defined as water-soluble carbohydrates (WSC) in the rations. The fermentors were fed $52 \mathrm{~g}$ of DM twice daily of diets containing $17 \%$ crude protein, $28 \%$ neutral detergent fiber, and $45 \%$ nonfiber carbohydrates. Liquid treatments were pipetted into each fermentor. After 7 $\mathrm{d}$ of adaptation, samples were collected for analyses of volatile fatty acids (VFA), lactate, and ammonia, and fermentors' $\mathrm{pH}$ were measured at time points after the morning feeding for $3 \mathrm{~d}$. Pooled samples from effluent containers were collected for similar analyses, nutrient flow, and $\mathrm{N}$ metabolism. Data were statistically ana-
\end{abstract}

Received June 2, 2021.

Accepted October 18, 2021.

*Current address: Department of Animal, Veterinary, and Food Sciences, University of Idaho, Moscow 83844.

tCurrent address: Department of Animal Science, Penn State University, University Park 16802.

$\ddagger$ Current address: Department of Animal Sciences, Federal

University of Tocantins, 77001-090 Tocantins, Brazil.

$\S$ Corresponding author: afaciola@ufl.edu lyzed using Proc MIXED of SAS version 9.4 (SAS Institute Inc.); fixed effects included treatment and time, and random effects included fermentor, period, and square. The interaction of treatment and time was included for the kinetics samples. The TCWP and MOL treatments maintained greater fermentor $\mathrm{pH}$ compared with CWP. Total VFA concentration was increased in CWP compared with MOL. The acetate:propionate ratio was increased in TCWP compared with CON, due to tendencies of increased acetate molar proportion and decreased propionate molar proportion in TCWP. Lactate concentration was increased in MOL. Digestibility of WSC was increased in the diets that replaced corn with byproducts. The partial replacement of $4 \%$ of DM from corn starch with the sugars in byproducts had minimal effects on ruminal microbial fermentation and increased $\mathrm{pH}$. Treated CWP had similar effects to molasses.

Key words: carbohydrates, lactose, molasses, starch

\section{INTRODUCTION}

Dairy nutritionists traditionally classify carbohydrates into structural and nonstructural carbohydrates (NRC, 2001). Nonstructural carbohydrates include starches and sugars found inside the plant cell. Starch can compose up to $70 \%$ of the DM found in corn grain (Ferraretto et al., 2013), a common feedstuff fed in cattle diets. Starch increases the energy density of the diet, which, when properly formulated, can allow for improved production (Huntington, 1997). In dairy diets, starch recommendations range from $20 \%$ in a dry cow diet to greater than $35 \%$ in a lactating cow diet (Grant, 2019). A possible downfall of feeding highstarch diets is that it may reduce NDF digestibility (Firkins et al., 2001; Ferraretto et al., 2013) because it can reduce ruminal $\mathrm{pH}$, favoring against cellulolytic bacteria (Russell and Wilson, 1996), and may lead to ruminal acidosis (Stone, 2004). A potential strategy to prevent reductions in NDF digestibility is to partially 
replace starch with other forms of nonstructural carbohydrates such as readily fermentable carbohydrates in the form of sugar sources (Heldt et al., 1999; Broderick et al., 2008).

Molasses and whey are byproducts of sugar and cheese production, respectively, and are widely used in ruminant diets. Whey permeate is produced by the removal of protein and other solids from whey by ultrafiltration, and it can be condensed through partial water removal. As fed, molasses is composed of about $50 \%$ sucrose (Nikodinovic-Runic et al., 2013), whereas whey permeate is composed of about $5 \%$ lactose (Cassano et al., 2019). Both molasses and condensed whey permeate can be added as a partial replacement for corn grain, ranging from 3 to $6 \%$, in dairy cattle diets as a source of economical alternative feedstuffs without compromising cow productivity (Baurhoo and Mustafa, 2014). Additionally, the inclusion of dietary sugars has been shown to maintain nutrient digestibility of DM, OM, NDF, and starch (Penner and Oba, 2009), increase molar proportion of butyrate (Chamberlain et al., 1993), and improve microbial protein production (Ribeiro et al., 2005) without decreasing ruminal $\mathrm{pH}$. Sugars can be included at 1.5 to $8 \%$ of DM in lactating dairy cattle diets (Firkins et al., 2001; de Ondarza et al., 2017). Although a few studies have shown that sucrose and lactose may be included in dairy diets to maintain production in lactating cows (DeFrain et al., 2006; Broderick et al., 2008), little research has been conducted on inclusion of condensed whey permeate and treated condensed whey permeate.

Due to lactose crystallization, hard crystal deposits could be found at the bottom of holding tanks when storing condensed whey permeate. Treatment of condensed whey permeate with a caustic agent aims to improve shelf life as a result of stabilization, preventing crystallization of the lactose in condensed whey. This stabilization of the structure of lactose crystals in their uncrystallized form and the introduction of sodium hydroxide into the permeate may prevent reductions in ruminal $\mathrm{pH}$ and aid fermentation of condensed whey permeate in the rumen (Harris and Mostyn, 2012). The condensed whey permeate had a lighter color and visually seemed to have more deposition at the bottom, whereas the treated condensed whey permeate had a darker color and had visually less deposition at the bottom of the container.

The objective of this experiment was to evaluate whether the partial replacement of corn grain with molasses or condensed whey permeate in a dual-flow continuous culture system can help maintain nutrient digestion of a lactating cow diet by mixed ruminal microorganisms. Furthermore, we aimed to evaluate whether treating condensed whey permeate with so- dium hydroxide before feeding could increase nutrient digestibility and use by mixed ruminal microorganisms. We hypothesized that partial replacement of corn starch with sugars from molasses byproducts or condensed whey permeate would maintain adequate ruminal microbial fermentation through maintenance of $\mathrm{pH}$ and nutrient digestibility in the ruminal fluid and favorable formation of end products such as VFA. Additionally, we hypothesized that treatment of condensed whey permeate with sodium hydroxide would help prevent reductions in $\mathrm{pH}$ and improve its effects on fermentation and increase its rate of fermentation by mixed ruminal microorganisms through prevention of crystallization of the lactose in condensed whey permeate.

\section{MATERIALS AND METHODS}

The University of Florida (Gainesville) Institutional Animal Use and Care Committee approved all the procedures for animal care and handling required for this experiment.

\section{Experimental Design and Diets}

Eight dual-flow continuous culture fermentors were used in a replicated $4 \times 4$ Latin square design, with individual fermentors as the experimental units. The experiment consisted of 4 fermentation periods of $10 \mathrm{~d}$ each, consisting of $7 \mathrm{~d}$ of adaptation and $3 \mathrm{~d}$ of sampling. Sequences of 4 experimental diets, 1 per period, were randomly assigned to fermentors. The diets each included different sources of carbohydrates (Table 1). The control diet (CON) was formulated with corn grain, whereas the other diets were formulated by replacing a percentage of corn grain with either sugarcane molasses (MOL; $6.58 \%$ ), condensed whey permeate (CWP; $4.37 \%$ ), or treated condensed whey permeate (TCWP; $4.61 \%$ ). The diets were formulated for similar nutrient composition, differing only in the source of carbohydrate, as either starch or water-soluble carbohydrates (WSC; sugar). The starch from corn in the control diet was partially replaced, with $50 \%$ of sugar coming from either molasses, condensed whey permeate, or treated condensed whey permeate, based on the WSC concentrations of the byproducts. The replacement factor of $50 \%$ of sugar coming from each byproduct allowed the inclusion rate of the sugars to be within 1.5 and $8 \%$ of DM, an acceptable rate for inclusion of sugars in the dairy cow diet. The condensed whey permeate was treated with $0.5 \%$ by weight of sodium hydroxide to $32 \%$ by weight of lactose, to raise the $\mathrm{pH}$ from below 8 to 8 , reducing the crystallization of lactose, a procedure developed to improve its shelf life (Harris and Mostyn, 
Table 1. Ingredient and chemical composition of the experimental diets

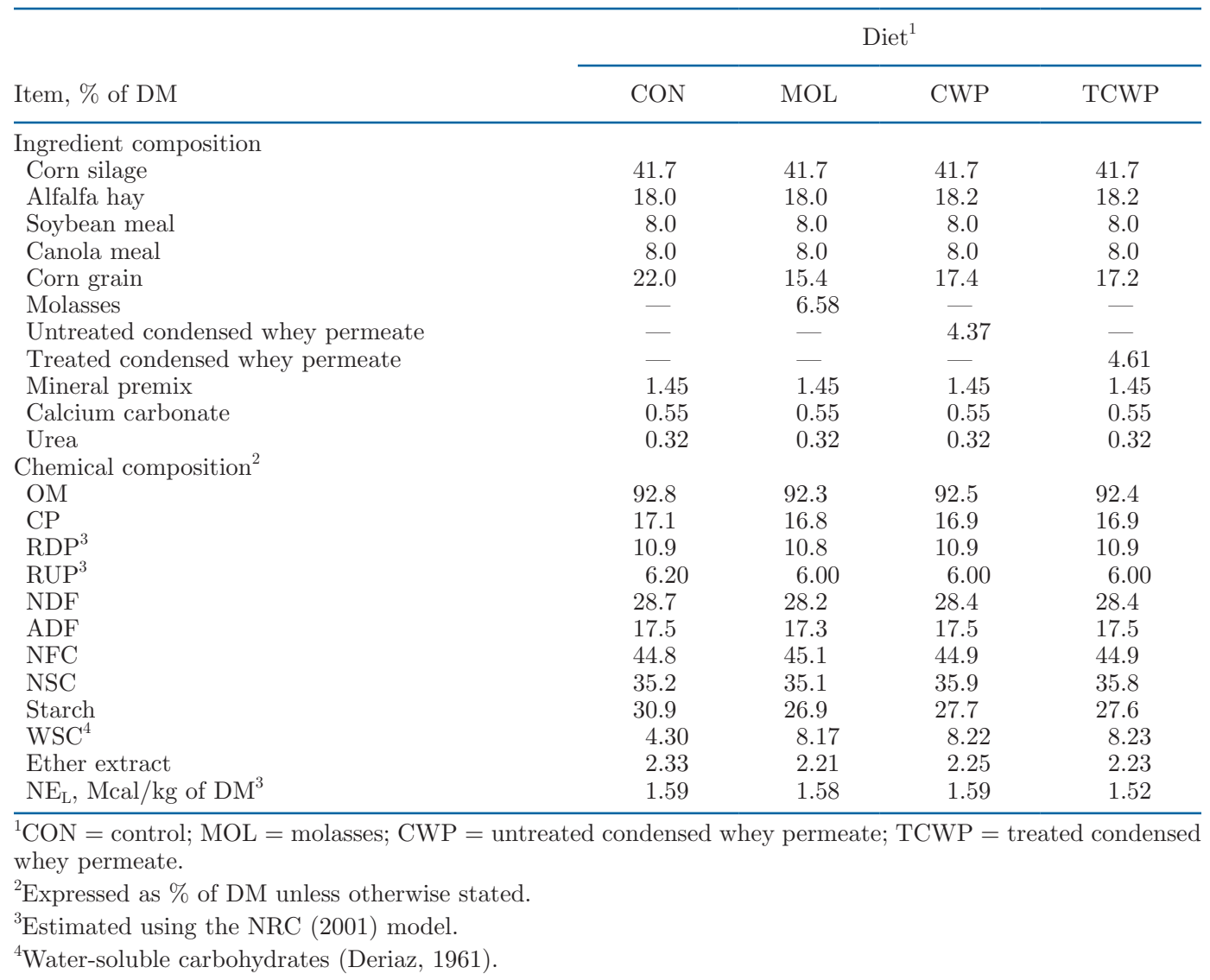

2012). Experimental diets were formulated according to NRC (2001) recommendation for a lactating Holstein cow with $680 \mathrm{~kg} \mathrm{BW}$, producing $45 \mathrm{~kg}$ of milk per day with milk fat, protein, and lactose percentages of $3.5 \%$, $3.0 \%$, and $4.8 \%$, respectively.

Nutrient composition of dry feed ingredients was determined in samples ground through a 1-mm screen in a Wiley mill (model no. 2, Arthur H. Thomas Co.) and sent for analysis to Rock River Laboratories (Watertown, WI). Samples were analyzed for DM (Shreve et al., 2006); ash (AOAC, 1990, method 942.05); NDF and ADF (analyzed sequentially using the Ankom system; Schlau et al., 2021; Ankom Technology, 2014, Appen$\operatorname{dix} \mathrm{A}, \mathrm{ADF}$ method), with ash and with heat-stable $\alpha$-amylase and sodium sulfite for NDF; starch (Hall, 2009); WSC, with sucrose used as the standard to develop the calibration curve and a known hay and corn silage run in each batch to check the accuracy of the curve (Dubois et al., 1956); crude fat (modified AOCS Am5-04; AOCS, 2017); and CP (AOAC International, 2000, method 990.03). Liquid feed samples were analyzed using the same methods at Rock River Laboratories, and partial chemical composition is presented in Table 2. The experimental diets were formulated based on chemical composition of individual feed ingredients. Corn silage was dried for $72 \mathrm{~h}$ in a $60^{\circ} \mathrm{C}$ forced-air oven; then it was ground to $2 \mathrm{~mm}$ and used in the diets. Soybean meal and corn grain were ground to $2 \mathrm{~mm}$. Alfalfa hay and canola meal were included as pellets, as purchased, in the diets. Each fermentor was fed the corresponding diet, consisting of $106 \mathrm{~g}$ of DM per day, including dry and liquid feed divided into 2 feeding times, at 0800 and $1800 \mathrm{~h}$. Liquid feeds (molasses and condensed whey permeate) were measured and dosed into each corresponding fermentor at each feeding time using a needleless syringe.

\section{Dual-Flow Continuous Culture System Operation}

A dual-flow continuous culture system, as developed by Hoover et al. (1976) and described by Arce-Cordero et al. (2021b) and Wenner et al. (2021), was used for this experiment. The fermentation vessels used had an average volumetric capacity of $1.82 \mathrm{~L}$ when filled until the solid effluent outflow port. To stimulate fermentation by microorganisms, artificial saliva was infused continuously (Weller and Pilgrim, 1974) at a rate of 3.1 $\mathrm{mL} / \mathrm{min}$, with partial removal of fermentation liquid 
effluent at $1.55 \mathrm{~mL} / \mathrm{min}$, which allows the removal of liquid and solid effluents to be controlled at a rate of $11 \%$ and $5.5 \% / \mathrm{h}$ respectively. Constant infusion of $\mathrm{N}_{2}$ gas maintained an anaerobic environment $(200 \mathrm{~mL}$ of $\left.\mathrm{N}_{2} / \mathrm{min}\right)$, and constant temperature $\left(39^{\circ} \mathrm{C}\right)$ and agitation $(100 \mathrm{rpm})$ were maintained throughout.

Two ruminally cannulated Holstein cows consuming a diet (DM basis: 60\% whole-plant corn silage, $12.5 \%$ ground corn, $13 \%$ citrus pulp, $12 \%$ soybean meal, and $2.5 \%$ mineral and vitamin mix) similar to the control diet were used as ruminal content donors. Ruminal contents were collected from both cows approximately $1 \mathrm{~h}$ after feeding and filtered through 4 layers of cheesecloth into prewarmed flasks (Thermos) for transportation to the laboratory. In the laboratory, each fermentor was prewarmed and infused with $\mathrm{N}_{2}$ gas before inoculation. Each fermentor was inoculated with a 50:50 mix (vol/vol) of the ruminal fluid collected from both cows until the incubated rumen fluid level reached the solid effluent outflow. On d 5 of each period, artificial saliva was exchanged for ${ }^{15} \mathrm{~N}$-enriched saliva, with $1.54 \mathrm{~g}$ of ammonium sulfate ${ }^{15} \mathrm{~N}$ per $20 \mathrm{~L}$, to replace $0.71 \mathrm{~g}$ of urea. To create a steady state of ${ }^{15} \mathrm{~N}$ before changing the saliva, a pulse dose of labeled ammonium sulfate provided $0.1733 \mathrm{~g}$ of $10.2 \%$ excess $\left({ }^{15} \mathrm{NH}_{4}\right)_{2} \mathrm{SO}_{4}$ (Sigma-Aldrich) per fermentor. Ammonium sulfate was continuously added to the system as a marker in the artificial saliva, at a rate of $0.077 \mathrm{~g} / \mathrm{L}$, until the end of each experimental period. On $\mathrm{d} 7$ the solid and liquid effluent containers were placed in an ice bath at $1^{\circ} \mathrm{C}$ to prevent any further microbial fermentation. At the end of $\mathrm{d} 10$, allowing for $3 \mathrm{~d}$ of collections, the fermentors were disassembled, cleaned, and reassembled for the following period.

Table 2. Partial chemical composition of corn grain versus sugarcontaining byproducts used in the experimental diets testing the substitution of starch with sugars in a dual-flow continuous culture system

\begin{tabular}{lcccc}
\hline \multirow{2}{*}{$\begin{array}{l}\text { Chemical } \\
\text { composition }^{1}\end{array}$} & Corn & Molasses & CWP $^{2}$ & TCWP $^{3}$ \\
\cline { 2 - 5 } & 92.9 & 69.8 & 32.3 & 29.5 \\
DM & 8.09 & 4.03 & 3.10 & 3.34 \\
CP & 68.1 & 7.48 & ND $^{4}$ & 0.79 \\
Starch & 2.07 & 60.8 & 91.7 & 86.9 \\
WSC $^{5}$ & 2.20 & 0.29 & 0.31 & ND \\
Ether extract & 1.51 & 10.6 & 9.35 & 10.1 \\
Ash & &
\end{tabular}

${ }^{1}$ Expressed as \% DM unless otherwise stated.

${ }^{2} \mathrm{CWP}=$ condensed whey permeate.

${ }^{3}$ TCWP $=$ condensed whey permeate treated with a caustic agent. ${ }^{4} \mathrm{ND}=$ not detected.

${ }^{5}$ Water-soluble carbohydrates (Deriaz, 1961).

\section{Collection of Data and Samples}

Fermentor $\mathrm{pH}$ was measured at $0,1,2,4,6,8$, and 10 $\mathrm{h}$ after feeding from each fermentor on d 8,9 , and 10 , and samples were collected from inside the fermentors and filtered through 4 layers of cheesecloth. One 10-mL sample was immediately mixed with $0.1 \mathrm{~mL}$ of $50 \%$ sulfuric acid for later VFA and $\mathrm{NH}_{3}-\mathrm{N}$ analyses. Another sample, approximately $1 \mathrm{~mL}$ of filtered fluid, was collected for lactate analysis. All samples were stored at $-20^{\circ} \mathrm{C}$ for later processing.

Background samples of homogenized liquid and solid effluents from each fermentor and artificial saliva were collected on d 5. Samples were stored at $-20^{\circ} \mathrm{C}$ for analysis of DM, ash, and ${ }^{15} \mathrm{~N}$ abundance. From d 7 to 10 , before morning feeding, both liquid and solid effluent containers were weighed, their contents combined and homogenized using a hand mixer for $30 \mathrm{~s}$, and stored at $-20^{\circ} \mathrm{C}$ for subsequent analysis of $\mathrm{DM}$, ash, NDF, starch, WSC, and ${ }^{15} \mathrm{~N}$ abundance. Pooled samples representing the whole day of fermentation for VFA, $\mathrm{NH}_{3}-\mathrm{N}$, and lactate were also collected from the homogenized sample by filtering through 4 layers of cheesecloth. Representative digesta and pool samples were collected in the mornings to represent $24 \mathrm{~h}$ of fermentation for the previous day.

At the end of d 10, a bacterial pellet was harvested from the total contents of each fermentor through 3 consecutive centrifugations, as outlined by Krizsan et al. (2010). Fermentor contents were blended for $30 \mathrm{~s}$ using a blender with $200 \mathrm{~mL}$ of saline solution $(0.9 \%$ $\mathrm{NaCl}$ ), squeezed through 4 layers of cheesecloth, and then rinsed with another $200 \mathrm{~mL}$ of saline solution. The filtered sample was centrifuged (Sorvall RC-5B Refrigerated Superspeed Centrifuge, DuPont Instruments) at $1,000 \times g$ for $10 \mathrm{~min}$ at $4^{\circ} \mathrm{C}$, and the supernatant, free of feed particles, was collected for the next centrifugation at $11,250 \times g$ for $20 \mathrm{~min}$ at $4^{\circ} \mathrm{C}$ to isolate the bacterial pellet. The supernatant was discarded, and the bacterial pellet was resuspended in $200 \mathrm{~mL}$ of McDougall's solution to purify the pellet. The final centrifugation was performed at $16,250 \times g$ for $20 \mathrm{~min}$ at $4^{\circ} \mathrm{C}$. The bacterial pellet was transferred to a new container and stored at $-20^{\circ} \mathrm{C}$ to be freeze-dried. Dry matter, ash, total $\mathrm{N}$, and ${ }^{15} \mathrm{~N}$ abundance were analyzed from the bacterial pellet. All background, digesta, and bacterial samples were freeze-dried and ground using a mortar and pestle $24 \mathrm{~h}$ after freeze-drying was complete.

\section{Chemical Analyses}

For VFA and $\mathrm{NH}_{3}-\mathrm{N}$ analyses, ruminal fluid samples were thawed at room temperature and centrifuged at $10,000 \times g$ for $15 \mathrm{~min}$ at $4^{\circ} \mathrm{C}$, and the supernatant 
was collected for analysis. Samples for $\mathrm{NH}_{3}-\mathrm{N}$ concentration were analyzed using the method described by Broderick and Kang (1980). The supernatant sample collected from the initial centrifugation was analyzed in a 96-well flat-bottom plate using a phenol-hypochlorite solution. After initial centrifugation, VFA samples were further processed following the Ruiz-Moreno et al. (2015) method. A crotonic and metaphosphoric acid solution was added to the supernatant at a 1:5 ratio and allowed to freeze overnight. The samples were later thawed and centrifuged at $10,000 \times g$ for 15 min at $4^{\circ} \mathrm{C}$, and ethyl acetate was mixed into the supernatant in a 2:1 ratio, vortexed, and allowed to settle. The top layer was transferred to a chromatography vial for analysis. Analysis of total and individual VFA was conducted using gas chromatography (Agilent 7820A GC, Agilent Technologies) with a flame ionization detector and a capillary column $(\mathrm{CP}-\mathrm{WA} \times 58$ FFAP $25 \mathrm{~m} 0.53 \mathrm{~mm}$, Varian CP7767, Varian Analytical Instruments) maintained at $110^{\circ} \mathrm{C}$, with injector temperature at $200^{\circ} \mathrm{C}$ and detector at $220^{\circ} \mathrm{C}$. Lactate was determined using a kit (R-Biopharm) based on the procedure of Niederholtmeyer et al. (2010).

Diet ingredients and freeze-dried digesta samples were analyzed for DM (AOAC, 1990; method 930.15) and ash (AOAC, 1990; method 942.05); NDF was analyzed (Van Soest et al., 1991; Schlau et al., 2021) with heat-stable $\alpha$-amylase and sodium sulfite modified for Ankom 200 Fiber Analyzer (Ankom Technology) for NDF; starch was analyzed using methods described in Hall et al. (2015); WSC was analyzed using methods described in Deriaz (1961); and total N was analyzed (AOAC International, 2000; method 990.03) using rapid combustion with a micro elemental $\mathrm{N}$ analyzer (Vario Micro Cube, Elementar). The atomic percentage of ${ }^{15} \mathrm{~N}$ was determined using isotope ratio mass spectrometry and reported as the fractional abundance of isotopes $\left({ }^{14} \mathrm{~N} /{ }^{15} \mathrm{~N}\right) \times 100$.

About $0.02 \mathrm{~g}$ of background, digesta, and bacteria samples were combined with $2.0-\mathrm{mm}$ zirconia beads to be ground using a Precellys 24 Bead Mill Homogenizer (Bertin Instruments) at $5,500 \times g$ for $10 \mathrm{~s}$ at room temperature for ${ }^{15} \mathrm{~N}$ analysis. Based on expected ${ }^{15} \mathrm{~N}$ concentrations, 4, 2, and $1 \mathrm{mg}$, respectively, of ground samples were weighed into 8 - $\mathrm{mm} \times 5$-mm tin capsules using a microbalance (Excellence Plus XP Micro Balance, Mettler-Toledo $\mathrm{GmbH}$ ). For complete evaporation of residual $\mathrm{NH}_{3}-\mathrm{N}, 35 \mu \mathrm{L}$ of $\mathrm{K}_{2} \mathrm{CO}_{3}(10 \mathrm{~g} / \mathrm{L})$ was pipetted into each capsule and placed in an oven at $40^{\circ} \mathrm{C}$ and allowed to dry overnight (Reynal et al., 2005). For background and bacteria samples, DM, ash, and concentration of total $\mathrm{N}$ were analyzed as described previously.

\section{Calculations}

Flow of bacterial $\mathrm{N}$ and bacterial efficiency were determined as follows:

$$
\text { Bacterial } \mathrm{N} \text { flow }(\mathrm{g} / \mathrm{d})=
$$

(NAN flow $\times \%$ atom excess of ${ }^{15} \mathrm{~N}$ of NAN effluent)/

(\% atom excess of ${ }^{15} \mathrm{~N}$ of bacteria pellet).

The percent excess of ${ }^{15} \mathrm{~N}$ of NAN effluent was obtained by subtracting $\%$ atom ${ }^{15} \mathrm{~N}$ in the background from the $\%$ atom excess of ${ }^{15} \mathrm{~N}$ of NAN effluent (Calsamiglia et al., 1996).

Flows of $\mathrm{NH}_{3}-\mathrm{N}, \mathrm{NAN}$, and $\mathrm{N}$ metabolism were determined using Bach and Stern (1999):

$$
\begin{gathered}
\mathrm{NH}_{3}-\mathrm{N} \text { flow }(\mathrm{g} / \mathrm{d})=\text { effluent } \mathrm{NH}_{3}-\mathrm{N} \text { concentration } \\
(\mathrm{mg} / \mathrm{dL}) / 1,000 \times[\text { total effluent flow }(\mathrm{g}) / 100] \\
\mathrm{NAN} \text { flow }(\mathrm{g} / \mathrm{d})=\text { effluent grams of total } \mathrm{N} \\
- \text { effluent grams of } \mathrm{NH}_{3}-\mathrm{N} ;
\end{gathered}
$$

Dietary $\mathrm{N}$ flow $(\mathrm{g} / \mathrm{d})=$ effluent grams of NAN

$$
\text { - effluent grams of bacterial N; }
$$

Bacterial efficiency $=$ grams of bacterial $\mathrm{N}$ flow $/$

kilograms of OM truly digested

(Calsamiglia et al., 1996);

Efficiency of $\mathrm{N}$ use $=$ (grams of bacterial $\mathrm{N} /$ grams of available N) $\times 100($ Bach and Stern, 1999)

True digestibility of nutrients (OM, CP, NDF, WSC, and starch) was estimated according to Soder et al. (2013):

Percent nutrient digestibility (DM basis) $=$

$100 \times$ [grams of nutrient intake - (effluent grams of nutrient - saliva grams of nutrient

- bacteria grams of nutrient)]

$\div$ grams of nutrient intake.

\section{Statistical Analysis}

Statistical analysis of data was performed with the MIXED procedure of SAS 9.4 (SAS Institute Inc.). Data were analyzed as a duplicated $4 \times 4$ Latin square 
design. The model used for evaluation of kinetics of $\mathrm{pH}$ and concentration of $\mathrm{NH}_{3}-\mathrm{N}$, lactate, and VFA over time was analyzed through repeated measures, which included the fixed effects of treatment, time, and interaction of treatment $\times$ time, and the random effects of fermentor, period, and square. The effect of experimental treatment was evaluated through multiple comparisons by comparing all treatment means, applying Bonferroni means separation if the treatment was significant. Additionally, mean separation by hour was performed for the kinetics samples. The covariance structure used was the one that yielded the lowest Akaike information criterion for each variable. The 2 most used ones were compound symmetry and autoregressive heterogeneous. The model used for the evaluation of the pooled $\mathrm{NH}_{3} \mathrm{~N}$, VFA, lactate, $\mathrm{N}$ metabolism, and nutrient digestibility included the fixed effects of day and treatment, and the random effects of fermentor, period, and square. The comparisons were the same as those used for the kinetics analysis. Results are reported as least squares means \pm standard error of the means. Significance was declared at $P \leq 0.05$ and tendencies at $0.05<P \leq 0.10$.

\section{RESULTS AND DISCUSSION}

Partial chemical results from the ingredients listed in Table 2 are within the range observed in the literature. Fiber fractions were not included because they are virtually zero in CWP and TCWP. Analysis of WSC is a fairly crude assay, as the phenol-sulfuric acid assay is a nonspecific carbohydrate assay. It is likely that WSC was slightly high in CWP and TCWP, but very few studies have adequately compared those. It is also possible that soluble starch may have overlapped with
WSC. Starch accrual following treatment in TCWP was not expected, but it was quite low and may not be of biological significance. This could have been an artifact of the starch assay. For example, it is not unusual to have minor starch values for alfalfa samples. Overall, values were within expected range.

\section{pH and Ammonia}

Replacing $4 \%$ of diet DM from corn starch with sugars found in byproducts had no significant effect between $\mathrm{CON}$ and the sugar treatments, but fermentor $\mathrm{pH}$ of MOL and TCWP increased compared with CWP $(P<0.05)$. The average fermentor $\mathrm{pH}$ of the CWP diet was 6.07 , whereas in MOL and TCWP it was 6.21 and 6.20 , respectively (Table 3 ). No difference in fermentor $\mathrm{pH}$ was observed between MOL and CON. Broderick et al. (2008) reported no difference in ruminal $\mathrm{pH}$ when sucrose replaced from 2.5 to 7.5 percentage units of corn starch in diets of lactating dairy cows. One possible explanation for the increase in $\mathrm{pH}$ seen in MOL compared with CWP could be the ability of microorganisms to use sucrose to make glycogen (Hall and Weimer, 2007). The storage of glycogen slows the rate of fermentation and release of fermentation acids, possibly leading to less depression of $\mathrm{pH}$ (Oba, 2011) with inclusion of molasses in the diet compared with condensed whey permeate.

Differences in $\mathrm{pH}$ observed between the 2 condensed whey permeate diets could be attributable to differences in the composition of the sugar in between condensed whey permeate and treated condensed whey permeate. Although both condensed whey permeate treatments received the same amount of WSC, they

Table 3. Effects of partially replacing corn grain with sugar containing byproducts on $\mathrm{pH}$ and $24-\mathrm{h} \mathrm{NH}_{3} \mathrm{~N}$, VFA, and lactate pool in a dual-flow continuous culture system

\begin{tabular}{lcccccc}
\hline \multicolumn{7}{c}{ Treatment $^{1}$} \\
\cline { 2 - 5 } Item & CON & MOL & CWP & TCWP & SEM & $P$-value \\
\cline { 2 - 5 } $\mathrm{pH}$ & $6.12^{\mathrm{ab}}$ & $6.21^{\mathrm{a}}$ & $6.07^{\mathrm{b}}$ & $6.20^{\mathrm{a}}$ & 0.08 & 0.04 \\
$\mathrm{NH}_{3} \mathrm{~N}, \mathrm{mg} / \mathrm{dL}$ & 21.57 & 21.31 & 20.98 & 22.41 & 1.62 & 0.74 \\
Total VFA, mM & $91.26^{\mathrm{ab}}$ & $89.34^{\mathrm{b}}$ & $93.37^{\mathrm{a}}$ & $90.89^{\mathrm{ab}}$ & 1.61 & 0.02 \\
VFA, \% of total VFA & & & & & & \\
Acetate (A) & 50.26 & 51.25 & 51.59 & 52.06 & 0.95 & 0.07 \\
Propionate (P) & 25.38 & 23.45 & 24.82 & 22.68 & 1.26 & 0.09 \\
Butyrate & 18.07 & 18.87 & 17.27 & 18.63 & 0.97 & 0.39 \\
Valerate & 2.46 & 2.46 & 2.50 & 2.46 & 0.12 & 0.96 \\
Isobutyrate & $0.78^{\mathrm{a}}$ & $0.74^{\mathrm{ab}}$ & $0.70^{\mathrm{b}}$ & $0.77^{\mathrm{ab}}$ & 0.05 & 0.03 \\
Isovalerate & 2.20 & 2.19 & 2.29 & 2.35 & 0.48 & 0.16 \\
Caproate & $0.85^{\mathrm{ab}}$ & $1.04^{\mathrm{ab}}$ & $0.83^{\mathrm{b}}$ & $1.06^{\mathrm{a}}$ & 0.17 & 0.03 \\
A:P & $2.01^{\mathrm{b}}$ & $2.20^{\mathrm{ab}}$ & $2.14^{\mathrm{ab}}$ & $2.32^{\mathrm{a}}$ & 0.12 & 0.03 \\
Lactate, m $M$ & $0.20^{\mathrm{b}}$ & $0.27^{\mathrm{a}}$ & $0.23^{\mathrm{b}}$ & $0.23^{\mathrm{b}}$ & 0.03 & $<0.01$ \\
\hline
\end{tabular}

${ }_{\mathrm{a}, \mathrm{b}}$ Means within a row with different subscripts differ $(P \leq 0.05)$.

${ }^{1} \mathrm{CON}=$ control; $\mathrm{MOL}=$ molasses; $\mathrm{CWP}=$ untreated condensed whey permeate; $\mathrm{TCWP}=$ treated condensed whey permeate. 


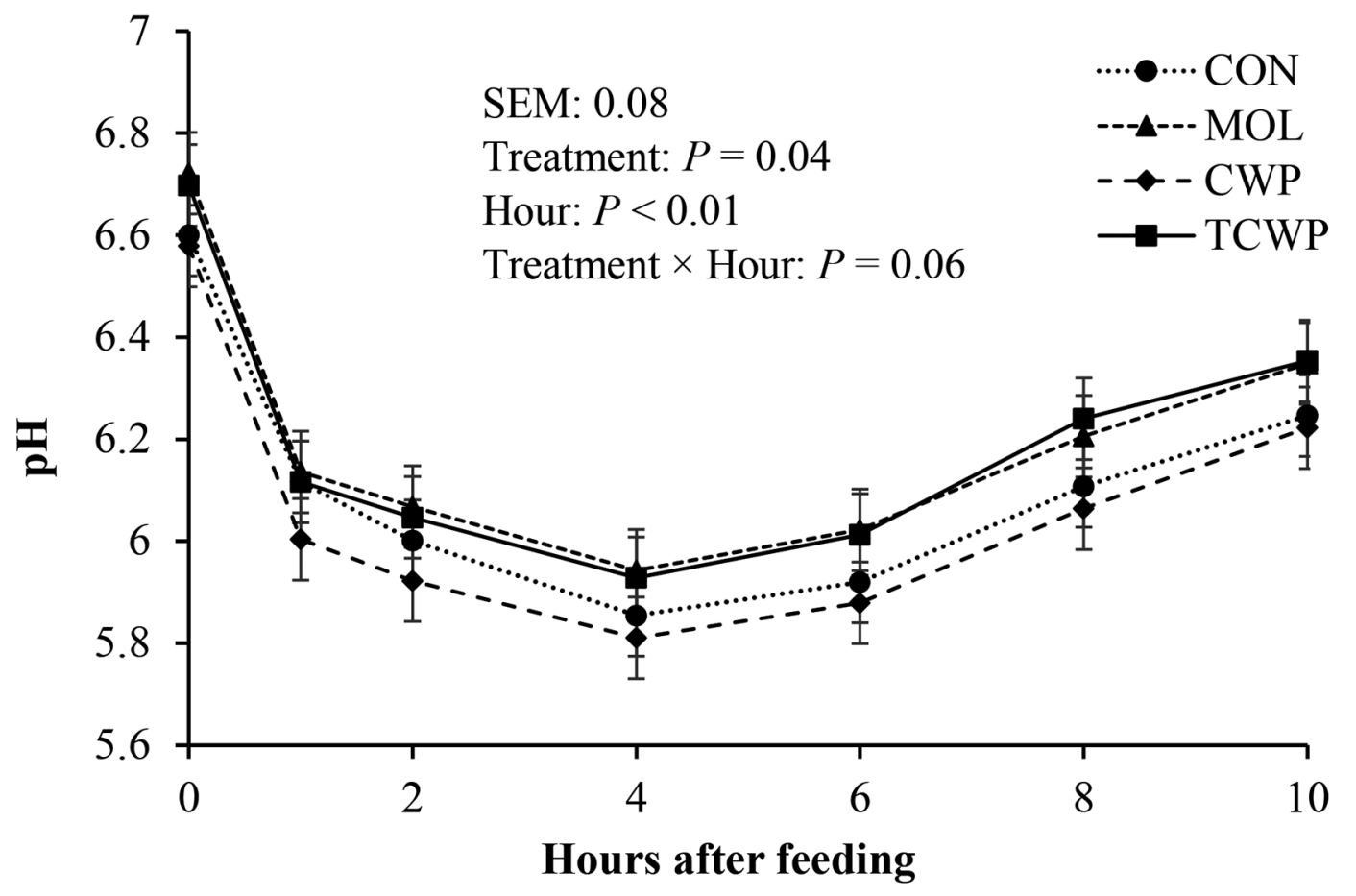

Figure 1. Average $\mathrm{pH}$ following feeding of treatments replacing corn with sugar-containing byproducts, and interaction of treatment $\times$ hour. Treatments: $\mathrm{CON}=$ formulated with corn $($ starch); $\mathrm{MOL}=$ formulated with molasses partially replacing $4 \%$ of diet DM of starch from corn with sugar from molasses; CWP = formulated with condensed whey permeate partially replacing $4 \%$ of diet DM of starch from corn with sugar from condensed whey permeate; TCWP $=$ formulated with treated condensed whey permeate partially replacing $4 \%$ of diet DM of starch from corn with sugar from condensed whey permeate treated with a caustic agent.

were present in different forms due to the caustic agent used in the treated condensed whey permeate. The use of sodium hydroxide for treating condensed whey permeate has been recommended to prevent formation of lactose crystals (Harris and Mostyn, 2012), which may result in slowed fermentation of crystallized compared with uncrystallized lactose. We did not detect such crystals in CWP in this experiment. However, the response of TCWP was more similar to MOL than to CWP in terms of changes in $\mathrm{pH}$, indicating that some change in fermentation characteristics of the treated lactose did occur. In addition to the reported reduction in lactose crystallization related to alkali treatment, it is possible that some portion of the lactose isomerized to lactulose (Zokaee et al., 2002), which could allow different fermentation characteristics in TCWP compared with CWP. However, analysis for lactulose was not performed on the substrates used in the current experiment. Additionally, the presence of $\mathrm{NaOH}$, an alkalizer, in the treated condensed whey permeate could also have prevented the decrease in $\mathrm{pH}$ seen in the untreated whey.

We observed a tendency for an effect of treatment by time interaction on $\mathrm{pH}(P=0.06$; Figure 1$)$. It was observed that MOL and TCWP failed to reduce $\mathrm{pH}$ and maintain a greater mean fermentor $\mathrm{pH}$ compared with CWP. Various studies have shown that lactose can be included in the diet without negative effects on ruminal pH (Schingoethe et al., 1980; DeFrain et al., 2006). However, as seen in this experiment, treatment of condensed whey permeate with $\mathrm{NaOH}$ changed its fermentation characteristics, which could have affected the fermentation rate of lactose. Thus, the addition of $\mathrm{NaOH}$ could help maintain $\mathrm{pH}$, compared with untreated condensed whey permeate. Additionally, when comparing condensed whey permeate to molasses, the lower concentration of total VFA with molasses did not depress $\mathrm{pH}$ compared with condensed whey permeate, which had a greater concentration of total VFA.

No effects in $\mathrm{NH}_{3}-\mathrm{N}$ concentration were seen (Table $3)$. With no differences, it is possible that sugar-utilizing bacteria prefer a different $\mathrm{N}$ source for growth (Maeng and Baldwin, 1976). Furthermore, $\mathrm{NH}_{3}-\mathrm{N}$ concentration is a net value and is affected by microbial utilization, amino acid use, and amino acid degradation to $\mathrm{NH}_{3^{-}}$ N (Argyle and Baldwin, 1989). Additionally, Hristov et al. (2005) have observed differences in $\mathrm{NH}_{3}-\mathrm{N}$ use by microorganisms using glucose or starch. Penner and Oba (2009) also observed no effect in $\mathrm{NH}_{3}-\mathrm{N}$ in vivo when 52 early-lactation Holstein cows were fed 
a high-sugar diet with added sucrose that had $8.4 \%$ total sugar, compared with a low-sugar diet that had no inclusion of sucrose and $4.5 \%$ total sugar. Vallimont et al. (2004) used a dual-flow continuous culture system to test the effects of partially and completely replacing $7.5 \%$ of corn starch with sugar and reported no change in total fermentor $\mathrm{NH}_{3}-\mathrm{N}$ concentration. Moreover, in a study by DeFrain et al. (2004), no effect on $\mathrm{NH}_{3}-\mathrm{N}$ was seen when liquid whey or pure lactose was added to lactating cow diets. Some studies have reported a decrease in $\mathrm{NH}_{3}-\mathrm{N}$ concentration in ruminal fluid when sucrose (Sannes et al., 2002; Broderick et al., 2008) or lactose was added to the diet (DeFrain et al., 2006). Increased concentrations of $\mathrm{NH}_{3}-\mathrm{N}$ have also been reported when feeding molasses. A 2-trial study by Broderick and Radloff (2004) reported a quadratic effect on ruminal $\mathrm{NH}_{3}-\mathrm{N}$ concentration with the inclusion of molasses in the diets. The lowest $\mathrm{NH}_{3}-\mathrm{N}$ concentration was observed with the lowest sugar content at $1.19 \mathrm{mg} /$ $\mathrm{dL}$ in one study, and the greatest $\mathrm{NH}_{3}-\mathrm{N}$ concentration was observed with a greater sugar content in the second study at $9.30 \mathrm{mg} / \mathrm{dL}$. Although it is expected that sugars will aid the capture of more degradable N (Sniffen et al., 1992), reports have been inconsistent when different sugars were fed. Additionally, more work in fermentors is needed to understand changes in $\mathrm{NH}_{3}$ $\mathrm{N}$, as there is a lack of exchange of end products in a fermentor compared with in vivo.

\section{Volatile Fatty Acids and Lactate}

Data for VFA and lactate concentrations are presented in Table 3. Total VFA concentration was greater in CWP compared with MOL $(P=0.02)$. The results in the present experiment correspond with that of Abdullah et al. (1992), where it was seen in cattle and buffaloes that inclusion of molasses in the diet decreases total VFA concentration. One possible reason for the lower total VFA seen in MOL could be, as discussed earlier, the storage of glycogen in microorganisms. If microorganisms use sucrose to make glycogen, a short-term energy storage (Hall and Weimer, 2007), then this storage delays and slows the production of fermentation acids. With this momentary reduction in fermentation, it is possible that the total VFA concentration could be decreased compared with a treatment that does not have sucrose supplementation, such as CWP. Another potential explanation is the increase in protozoa concentration from supplementing with molasses. Some protozoa are believed to be able to survive $10 \mathrm{~d}$ of fermentation in vitro (Hino et al., 1993). Nguyen and Preston (1999) report that supplementation of molasses increased the protozoa population in the rumen of swamp buffaloes, and Mendoza et al. (1993) reported that protozoa-free sheep tended to have greater concentrations of total VFA. Hence, inclusion of molasses in the diet could have increased the protozoa population, leading to a decrease in concentration of total VFA. Protozoa counts were not taken during this experiment; hence, further studies would need to be conducted to test this hypothesis. The results seen in VFA concentrations also correspond to the $\mathrm{pH}$ values as expected; Weisbjerg et al. (1998) reported that greater VFA concentration had lower $\mathrm{pH}$, as seen in CWP, and lower VFA concentration had a greater $\mathrm{pH}$, as seen in MOL.

When studying the effects of sugar supplementation on VFA profile, one would expect to observe an increase in the proportion of butyrate (Chamberlain et al., 1993; de Ondarza et al., 2017); this is attributed to the increased production of lactate, due to sugars favoring lactate-utilizing bacteria (Heldt et al., 1999), from which butyrate formation then occurs when the $\mathrm{pH}$ of the rumen is around 6.2. However, Baldwin et al. (1962) reported that, as the presence of carbohydrates and lactate in the diet increased, production of propionate by rumen microorganisms increased. In the present experiment, we found no effect on butyrate, in accordance with results seen in Broderick et al. (2008) and Penner and Oba (2009). It is possible that this lack of difference in butyrate concentration could be due to lack of retention of isotrichid protozoa, which have been shown to be important for butyrate production (Hall, 2011). The molar proportion of acetate tended to increase $(P=0.10)$, whereas propionate proportion tended to decrease in TCWP compared with CON $(P=0.10)$. Previous studies have demonstrated that, when sugar was used to replace dietary starch, propionate concentration decreased (Heldt et al., 1999; DeFrain et al., 2004). Without an observed change in butyrate, if the concentration of propionate decreased with TCWP, it can be expected that the proportion of acetate would increase. This can be seen in the acetate: propionate ratio as well. The TCWP treatment had a greater A:P ratio compared with $\mathrm{CON}(P=0.04)$. Russell (1998) reported that when $\mathrm{pH}$ in incubated rumen fluid decreased from 6.5 to 5.3, the A:P ratio decreased from 1.2 to 0.6 . It was seen that $25 \%$ of the change in the A:P ratio could be attributed to change in $\mathrm{pH}$. In the current experiment, TCWP, which had a greater $\mathrm{pH}$, tended to have a greater $\mathrm{A}: \mathrm{P}$ ratio compared with $\mathrm{CON}$, which had a lower $\mathrm{pH}$ and lower A:P ratio.

No treatment effects were observed on molar proportion of valerate and isovalerate; however, isobutyrate was lower in CWP $(P=0.05)$ compared with CON. Studies with sugars often do not report the effects on isoacids such as isobutyrate and isovalerate. However, in an in vitro setting it has been observed that, to a 
Table 4. Effects of replacement of corn grain with sugar-containing byproducts on digestibility in a dual-flow continuous culture system

\begin{tabular}{|c|c|c|c|c|c|c|}
\hline \multirow[b]{2}{*}{ Digestibility, ${ }^{1} \%$} & \multicolumn{4}{|c|}{ Treatment $^{2}$} & \multirow[b]{2}{*}{ SEM } & \multirow[b]{2}{*}{$P$-value } \\
\hline & $\mathrm{CON}$ & MOL & CWP & TCWP & & \\
\hline DM & 50.5 & 50.1 & 49.9 & 50.6 & 1.65 & 0.97 \\
\hline $\mathrm{OM}$ & 56.6 & 56.7 & 56.2 & 56.8 & 1.45 & 0.97 \\
\hline $\mathrm{CP}$ & 60.8 & 59.5 & 59.0 & 61.5 & 2.51 & 0.67 \\
\hline $\mathrm{NDF}$ & 48.6 & 48.2 & 47.5 & 48.7 & 2.46 & 0.89 \\
\hline Starch & 91.6 & 90.6 & 90.3 & 89.6 & 0.87 & 0.08 \\
\hline $\mathrm{WSC}^{3}$ & $83.5^{\mathrm{b}}$ & $88.7^{\mathrm{a}}$ & $91.6^{\mathrm{a}}$ & $91.0^{\mathrm{a}}$ & 1.19 & $<0.01$ \\
\hline
\end{tabular}

${ }_{\mathrm{a}, \mathrm{b}}$ Means within a row with different subscripts differ $(P \leq 0.05)$.

${ }^{1}$ True digestibility for DM, OM, CP, and dietary starch; apparent digestibility for NDF and WSC.

${ }^{2} \mathrm{CON}=$ control; $\mathrm{MOL}=$ molasses; $\mathrm{CWP}=$ untreated condensed whey permeate; $\mathrm{TCWP}=$ treated condensed whey permeate.

${ }^{3}$ Water-soluble carbohydrates (Deriaz, 1961).

lesser extent, these isoacids could increase the rate of cellulose digestion (Bentley et al., 1955). This should be a point of consideration when feeding diets with sugar components, given the concern for decreased NDF digestibility (Hall and Mertens, 2017). Little et al. (1967) tested the effect of valerate, isobutyrate, and isovalerate on cellulolytic digestion in a control medium and reported that valerate had the greatest stimulation on NDF digestibility, followed by isobutyrate, with no effect on digestibility seen with isovalerate. Although we found a decrease in the concentration of isobutyrate in CWP compared with CON, difference in NDF digestibility was observed (Table 4). It is unlikely that a small but significant change in the concentration of these branched-chained VFA would be the cause of a decrease in NDF digestibility. According to RomanGarcia et al. (2021), greater differences in concentrations of branched-chained VFA would be needed to alter NDF digestibility. Other factors such as dietary starch, diet particle size, and ruminal $\mathrm{pH}$ would likely have a greater effect on NDF digestibility.

Caproate is a ketogenic short-chain fatty acid (Kristensen and Harmon, 2005), and its role in ruminal metabolism is not well studied. The molar proportion of caproate was increased with TCWP compared with CWP $(P<0.01)$. Caproate is formed during the secondary fermentation of acetate (Ding et al., 2010); hence, a positive correlation between acetate and caproate exists, which agrees with the numerical pattern of our results. Likewise, a negative relationship exists between propionate and caproate (Ertl et al., 2015). This is also in agreement with results seen in TCWP, which had a lower proportion of propionate and a greater concentration of caproate, whereas CWP, which had a greater proportion of propionate, had lower caproate. More research will be needed to better understand the role of caproate in ruminal metabolism.
Lactate concentration was increased in MOL $(P<$ 0.05) compared with the other treatments. We also observed an interaction of treatment and time, as MOL concentration of lactate was greater in the first $4 \mathrm{~h}$ after feeding and continued to be greater compared with the other treatments $(P=0.05)$, as shown in Figure 2. Lactate production in the rumen can be increased by the inclusion of soluble carbohydrates (Cullen et al., 1986). Sucrose, the sugar component of molasses, consists of the monomers of glucose and fructose, and it has been shown that glucose and fructose are able to ferment faster than galactose. Glucose and galactose are the monosaccharides that make up the disaccharide lactose, the sugar component of condensed whey permeate. Weisbjerg et al. (1998) tested single doses of sugars in the rumen to estimate their rate of hydrolysis and reported their fermentation rates. As a result of dosing sucrose, a lower ruminal $\mathrm{pH}$ was observed compared with when lactose was dosed. With lactose, $\mathrm{pH}$ was greater and decreased at a slower rate compared with sucrose; thus, Weisbjerg and colleagues concluded that sucrose was able to ferment faster than lactose. An earlier experiment by Sutton (1968) demonstrated that when equal amounts of glucose, fructose, and galactose were mixed with ruminal contents, after $2 \mathrm{~h}$ glucose and fructose are almost completely fermented, whereas galactose was about $55 \%$ fermented. This would explain the more rapid fermentation and greater concentration of lactate produced the first $4 \mathrm{~h}$ from feeding MOL.

\section{N Flows and Metabolism}

Treatments did not affect $\mathrm{N}$ flow and metabolism (Table 5). Broderick et al. (2008) did not see improvements in $\mathrm{N}$ utilization with the inclusion of sucrose in lactating cow diets. Additionally, DeFrain et al. (2006) saw no change in milk urea $\mathrm{N}$ when lactose was given to 
cows pre- and postpartum. Other studies have reported increases in microbial production with supplementation of molasses. Srinivas and Gupta (1997) reported greater microbial production rate of protein when cattle were given urea-molasses supplements, possibly due to the synergy of $\mathrm{N}$ source and energy. Furthermore, Marsetyo et al. (2005) reported that increasing molasses supplementation increased microbial protein synthesis in sheep fed urea-treated barley straw, and no difference in $\mathrm{NH}_{3}-\mathrm{N}$ concentration was reported. However, those authors reported increased nitrogen, attributed to more NAN present, thus allowing increased bacterial efficiency due to the increased presence of nitrogen because nitrogen was not limiting. However, in the current study, no positive effects were observed upon microbial protein production or bacterial efficiency related to replacement of the starch from corn with sugars from byproducts.

\section{Nutrient Digestibility}

We detected no effects of treatments on digestibility of DM, OM, CP, or NDF (Table 4). Although there are concerns about the replacement of corn grain with sugar-containing byproducts in diets, due to potential of decreased NDF digestibility (Hall and Mertens, 2017), in the current experiment we found no adverse effects on NDF digestibility from starch replacement with sugars. Broderick and Radloff (2004) reported an increase in total-tract digestibility of NDF with molasses supplementation that peaked at a dietary sugar concentration of $7.2 \%$ of DM in lactating dairy cow diets. The increase they observed could have been due to their slightly lower dietary sugar total, compared with the $8 \%$ used in the current experiment.

Dietary starch digestibility tended to be greater in CON than in other treatments $(P=0.08)$. The WSC digestibility of CON was lower than for the other treatments $(P<0.01)$. Although a basal level of sugars is always present in the diet (Lee et al., 2003), the liquid byproduct inclusion increased WSC concentration for the sugar diets. With more readily fermentable carbohydrates present in the sugar treatments, WSC digestibility could be increased due to greater availability for digestion. Additionally, Hoover et al. (2006) reported that the sugars found in free-sugar-containing byproducts are more digestible than the sugars found in plantbased material. The digestibility levels of WSC in the sugar treatments were all around $90 \%$. It is possible that WSC digestibility was lower with CON because

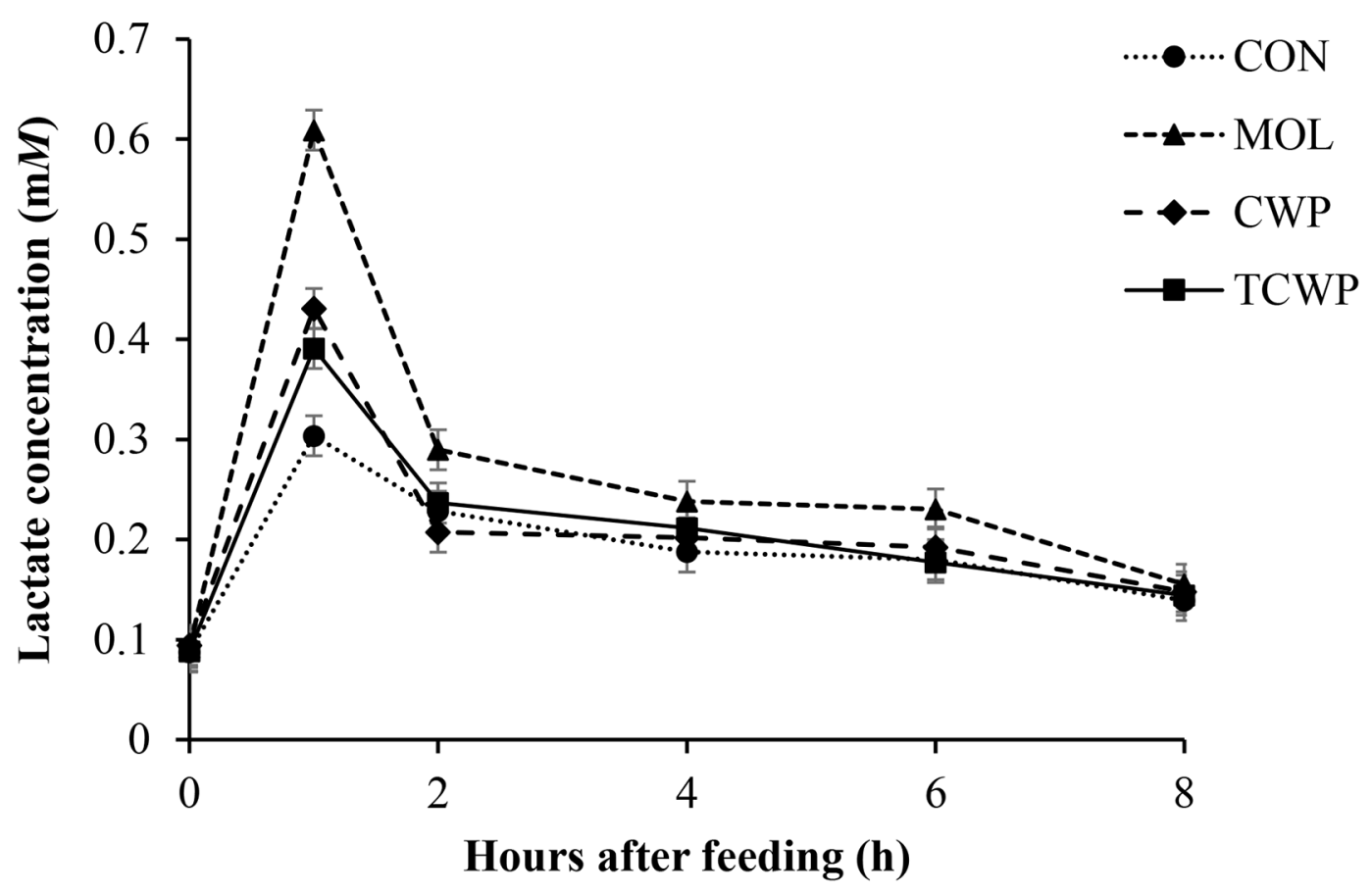

Figure 2. Concentration of lactate after feeding diets that replace corn with sugar-containing byproducts, and interaction of treatment $\times$ hour. Treatments: $\mathrm{CON}=$ formulated with corn (starch); $\mathrm{MOL}=$ formulated with molasses partially replacing $4 \%$ of diet DM of starch from corn with sugar from molasses; CWP = formulated with condensed whey permeate partially replacing $4 \%$ of diet DM of starch from corn with sugar from condensed whey permeate; TCWP = formulated with treated condensed whey permeate partially replacing $4 \%$ of diet DM of starch from corn with sugar from condensed whey permeate treated with a caustic agent. 
Table 5. Effects of replacement of corn grain with sugar-containing byproducts on $\mathrm{N}$ metabolism in a dualflow continuous culture system

\begin{tabular}{|c|c|c|c|c|c|c|}
\hline \multirow[b]{2}{*}{ Item } & \multicolumn{4}{|c|}{ Treatment $^{1}$} & \multirow[b]{2}{*}{ SEM } & \multirow[b]{2}{*}{$P$-value } \\
\hline & $\mathrm{CON}$ & MOL & CWP & TCWP & & \\
\hline \multicolumn{7}{|l|}{$\mathrm{N}$ flows, $\mathrm{g} / \mathrm{d}$} \\
\hline Total $\mathrm{N}^{2}$ & 2.92 & 3.02 & 2.91 & 2.92 & 0.08 & 0.52 \\
\hline $\mathrm{NH}_{3}-\mathrm{N}^{3}$ & 0.90 & 0.90 & 0.87 & 0.94 & 0.07 & 0.71 \\
\hline $\mathrm{NAN}^{4}$ & 2.02 & 2.12 & 2.03 & 1.97 & 0.06 & 0.25 \\
\hline Bacterial $\mathrm{N}^{5}$ & 1.00 & 1.08 & 0.98 & 1.02 & 0.06 & 0.40 \\
\hline Dietary $N^{6}$ & 1.02 & 1.04 & 1.05 & 0.99 & 0.07 & 0.72 \\
\hline $\mathrm{ENU}^{7}$ & 38.5 & 42.0 & 38.1 & 39.7 & 2.17 & 0.35 \\
\hline Bacterial efficiency $^{8}$ & 18.2 & 19.6 & 18.0 & 17.9 & 0.89 & 0.33 \\
\hline \multicolumn{7}{|c|}{$\begin{array}{l}{ }^{1} \mathrm{CON}=\text { control } ; \mathrm{MOL}=\text { molasses; } \mathrm{CWP}=\text { untreated condensed whey permeate; } \mathrm{TCWP}=\text { treated condense } \\
\text { whey permeate. }\end{array}$} \\
\hline \multicolumn{7}{|c|}{${ }^{2}$ Total $\mathrm{n}=\mathrm{NH}_{3}-\mathrm{N}+$ NAN (Bach and Stern, 1999). } \\
\hline \multicolumn{7}{|c|}{${ }^{3} \mathrm{NH}_{3}-\mathrm{N}($ ammonia $\mathrm{N})=$ effluent $\mathrm{NH}_{3}-\mathrm{N}(\mathrm{mg} / \mathrm{dL}) / 1,000 \times$ [total effluent flow $\left.(\mathrm{g}) / 100\right]$} \\
\hline \multicolumn{7}{|c|}{${ }^{4} \mathrm{NAN}=$ nonammonia $\mathrm{N}$ flow $(\mathrm{g} / \mathrm{d})=$ total $\mathrm{N}-\mathrm{NH}_{3}-\mathrm{N}$} \\
\hline \multicolumn{7}{|c|}{$\begin{array}{l}{ }^{5} \text { Bacterial } \mathrm{N} \text { flow }=\left(\mathrm{NAN} \text { flow } \times \% \text { atom excess of }{ }^{15} \mathrm{~N} \text { in } \mathrm{NAN} \text { effluent }\right) /\left(\% \text { atom excess of }{ }^{15} \mathrm{~N} \text { in bacter }\right. \\
\text { pellet }) \text {; Calsamiglia et al., } 1996 .\end{array}$} \\
\hline \multicolumn{7}{|c|}{${ }^{6}$ Dietary $\mathrm{N}$ flow $(\mathrm{g} / \mathrm{d})=\mathrm{NAN}-$ bacterial $\mathrm{N}$} \\
\hline \multicolumn{7}{|c|}{${ }^{7} \mathrm{ENU}($ efficiency of N use $)=($ grams of bacterial N/grams of available N $) \times 100($ Bach and Stern, 1999) } \\
\hline
\end{tabular}

the sugars in MOL and the condensed whey permeate treatments ferment faster than those present in $\mathrm{CON}$, due to the source of the WSC.

\section{CONCLUSIONS}

The partial replacement of corn starch with byproducts that contain either sucrose or lactose in the diet maintained ruminal microbial fermentation and had positive effects on $\mathrm{pH}$. In addition, condensed whey permeate treated with a caustic agent $(\mathrm{NaOH})$ was fermented similarly to molasses by mixed ruminal microorganisms in continuous culture. From helping maintain ruminal $\mathrm{pH}$ to maintaining nutrient digestibility, the treatment of sugars warrants more research in the future so that practical levels can be fed to dairy cows.

\section{ACKNOWLEDGMENTS}

Partial funding for this study was provided by Papillon Agricultural Company and MIN-AD Inc. (Easton, $\mathrm{MD})$. The authors have not stated any conflicts of interest.

\section{REFERENCES}

Abdullah, N., J. V. Nolan, M. Mahyuddin, and S. Jalaludin. 1992. Digestion and nitrogen conservation in cattle and buffaloes given rice straw with or without molasses. J. Agric. Sci. 119:255-263. https: //doi.org/10.1017/S0021859600014180.

Ankom Technology. 2014. Ankom 200 Fiber Analyzer Operator's Manual. Ankom Technology.
AOAC. 1990. Official Methods of Analysis. 13th ed. Assoc. Off. Anal. Chem.

AOAC International. 2000. Official Methods of Analysis. 17th ed. AOAC International.

AOCS. 2017. Official Methods and Recommended Practices of the AOCS. American Oil Chemists' Society.

Arce-Cordero, J. A., A. Ravelo, J. R. Vinyard, H. F. Monteiro, B. C. Agustinho, E. Sarmikasoglou, S. L. Bennet, and A. P. Faciola. 2021b. Effects of supplemental source of magnesium and inclusion of buffer on ruminal microbial fermentation in continuous culture. J. Dairy Sci. 104:7820-7829. https://doi.org/10.3168/jds .2020-20020.

Argyle, J. L., and R. L. Baldwin. 1989. Effects of amino acids and peptides on rumen microbial growth yields. J. Dairy Sci. 72:20172027. https://doi.org/10.3168/jds.S0022-0302(89)79325-5.

Bach, A., and M. D. Stern. 1999. Effects of different levels of methionine and ruminally undegradable protein on the amino acid profile of effluent from continuous culture fermenters. J. Anim. Sci. 77:3377-3384. https://doi.org/10.2527/1999.77123377x.

Baldwin, R. L., W. A. Wood, and R. S. Emery. 1962. Conversion of lactate- $\mathrm{C}^{14}$ to propionate by the rumen microflora. J. Bacteriol. 83:907-913. https://doi.org/10.1128/jb.83.4.907-913.1962.

Baurhoo, B., and A. Mustafa. 2014. Short communication: Effects of molasses supplementation on performance of lactating cows fed high-alfalfa silage diets. J. Dairy Sci. 97:1072-1076. https://doi .org/10.3168/jds.2013-6989.

Bentley, O. G., R. R. Johnson, T. V. Hershberger, J. H. Cline, and A. L. Moxon. 1955. Cellulolytic-factor activity of certain shortchain fatty acids for rumen microorganisms in vitro: Two figures. J. Nutr. 57:389-400. https://doi.org/10.1093/jn/57.3.389.

Broderick, G. A., and J. H. Kang. 1980. Automated simultaneous determination of ammonia and total amino acids in ruminal fluid and in vitro media. J. Dairy Sci. 63:64-75. https://doi.org/10 .3168/jds.S0022-0302(80)82888-8.

Broderick, G. A., N. D. Luchini, S. M. Reynal, G. A. Varga, and V. A Ishler. 2008. Effect on production of replacing dietary starch with sucrose in lactating dairy cows. J. Dairy Sci. 91:4801-4810. https: //doi.org/10.3168/jds.2008-1480.

Broderick, G. A., and W. J. Radloff. 2004. Effect of molasses supplementation on the production of lactating dairy cows fed diets based on alfalfa and corn silage. J. Dairy Sci. 87:2997-3009. https: //doi.org/10.3168/jds.S0022-0302(04)73431-1. 
Calsamiglia, S., M. D. Stern, and J. L. Firkins. 1996. Comparison of nitrogen-15 and purines as microbial markers in continuous culture. J. Anim. Sci. 74:1375-1381. https://doi.org/10.2527/1996 $.7461375 x$.

Cassano, A., C. Conidi, and R. Castro-Muñoz. 2019. Chapter 9: Current and future applications of nanofiltration in food processing. Pages 305-348 in Separation of Functional Molecules in Food by Membrane Technology. C. M. Galanakis, ed. Academic Press. https://doi.org/10.1016/C2017-0-02808-2.

Chamberlain, D. G., S. Robertson, and J. J. Choung. 1993. Sugars versus starch as supplements to grass silage: Effects on ruminal fermentation and the supply of microbial protein to the small intestine, estimated from the urinary excretion of purine derivatives, in sheep. J. Sci. Food Agric. 63:189-194. https://doi.org/10.1002/ jsfa.2740630204.

Cullen, A. J., D. L. Harmon, and T. G. Nagaraja. 1986. In vitro fermentation of sugars, grains, and by-product feeds in relation to initiation of ruminal lactate production. J. Dairy Sci. 69:2616-2621. https://doi.org/10.3168/jds.S0022-0302(86)80709-3.

de Ondarza, M. B., S. M. Emanuele, and C. J. Sniffen. 2017. Effect of increased dietary sugar on dairy cow performance as influenced by diet nutrient components and level of milk production. Prof. Anim. Sci. 33:700-707. https://doi.org/10.15232/pas.2017-01648.

DeFrain, J. M., A. Hippen, K. Kalscheur, and D. Schingoethe. 2006. Feeding lactose to increase ruminal butyrate and the metabolic status of transition dairy cows. J. Dairy Sci. 89:267-276. https:// doi.org/10.3168/jds.S0022-0302(06)72091-4.

DeFrain, J. M., A. R. Hippen, K. F. Kalscheur, and D. J. Schingoethe. 2004. Feeding lactose increases ruminal butyrate and plasma $\beta$-hydroxybutyrate in lactating dairy cows. J. Dairy Sci. 87:24862494. https://doi.org/10.3168/jds.S0022-0302(04)73373-1.

Deriaz, R. E. 1961. Routine analysis of carbohydrates and lignin in herbage. J. Sci. Food Agric. 12:152-160. https://doi.org/10.1002/ jsfa.2740120210.

Ding, H. B., G. Y. A. Tan, and J. Y. Wang. 2010. Caproate formation in mixed-culture fermentative hydrogen production. Bioresour. Technol. 101:9550-9559. https://doi.org/10.1016/j.biortech.2010 .07 .056 .

DuBois, M., K. A. Gilles, J. K. Hamilton, P. A. Rebers, and F. Smith. 1956. Colorimetric method for determination of sugars and related substances. Anal. Chem. 28:350-356. https://doi.org/10.1021/ ac60111a017.

Ertl, P., W. Knaus, B. U. Metzler-Zebeli, F. Klevenhusen, R. KhiaosaArd, and Q. Zebeli. 2015. Substitution of common concentrates with by-products modulated ruminal fermentation, nutrient degradation, and microbial community composition in vitro. J. Dairy Sci. 98:4762-4771. https://doi.org/10.3168/jds.2014-9063.

Ferraretto, L. F., P. M. Crump, and R. D. Shaver. 2013. Impact of cereal grain type and corn grain harvesting and processing methods on intake, digestion and milk production by dairy cows through a meta-analysis. J. Dairy Sci. 96:533-550. https://doi.org/10.3168/ jds.2012-5932.

Firkins, J. L., M. L. Eastridge, N. R. St-Pierre, and S. M. Noftsger. 2001. Effects of grain variability and processing on starch utilization by lactating dairy cattle. J. Anim. Sci. 79(E-Suppl.):E218 E238. https://doi.org/10.2527/jas2001.79E-SupplE218x.

Grant, R. 2019. Optimizing Starch Concentrations in Dairy Rations. Accessed Aug. 18, 2021. https://dairy-cattle.extension.org/ optimizing-starch-concentrations-in-dairy-rations/.

Hall, M. B. 2009. Determination of starch, including maltooligosaccharides, in animal feeds: Comparison of methods and a method recommended for AOAC collaborative study. J. AOAC Int. 92:42-49. https://doi.org/10.1093/jaoac/92.1.42.

Hall, M. B. 2011. Isotrichid protozoa influence conversion of glucose to glycogen and other microbial products. J. Dairy Sci. 94:4589-4602. https://doi.org/10.3168/jds.2010-3878.

Hall, M. B., J. Arbaugh, K. Binkerd, A. Carlson, T. Doan, T. Grant, C. Heuer, H. D. Inerowicz, B. Jean-Louis, R. Johnson, J. Jordan, D. Kondratko, E. Maciel, K. McCallum, D. Meyer, C. A. Odijk, A. Parganlija-Ramic, T. Potts, L. Ruiz, S. Snodgrass, D. Taysom, S. Trupia, B. Steinlicht, and D. Welch. 2015. Determination of dietary starch in animal feeds and pet food by an enzymatic-colorimetric method: Collaborative study. J. AOAC Int. 98:397-409. https://doi.org/10.5740/jaoacint.15-012.

Hall, M. B., and D. R. Mertens. 2017. A 100-Year Review: Carbohydrates - Characterization, digestion, and utilization. J. Dairy Sci. 100:10078-10093. https://doi.org/10.3168/jds.2017-13311.

Hall, M. B., and P. J. Weimer. 2007. Sucrose concentration alters fermentation kinetics, products, and carbon fates during in vitro fermentation with mixed ruminal microbes. J. Anim. Sci. 85:14671478. https://doi.org/10.2527/jas.2006-014.

Harris, J. M., and P. Mostyn. 2012. Methods for improving the storage and handling characteristics of condensed whey permeate and for utilizing condensed whey permeate in the feeding of a ruminant animal. US patent number 8,182,848 B2. Accessed June 2021. https://insight.rpxcorp.com/patent/US8182848B2.

Heldt, J. S., R. C. Cochran, G. K. Stokka, C. G. Farmer, C. P. Mathis, E. C. Titgemeyer, and T. G. Nagaraja. 1999. Effects of different supplemental sugars and starch fed in combination with degradable intake protein on low-quality forage use by beef steers. J. Anim. Sci. 77:2793-2802. https://doi.org/10.2527/1999.77102793x.

Hino, T., M. Sugiyama, and K. Okumura. 1993. Maintenance of protozoa and methanogens, and fiber digestion in rumen-simulating continuous culture. J. Gen. Appl. Microbiol. 39:35-45. https://doi .org/10.2323/jgam.39.35.

Hoover, W. H., B. A. Crooker, and C. J. Sniffen. 1976. Effects of differential solid-liquid removal rates on protozoa numbers in continuous cultures of rumen contents. J. Anim. Sci. 43:528-534. https:// doi.org/10.2527/jas1976.432528x.

Hoover, W. H., C. Tucker, J. Harris, C. J. Sniffen, and M. B. de Ondarza. 2006. Effects of nonstructural carbohydrate level and starch: sugar ratio on microbial metabolism in continuous culture of rumen contents. Anim. Feed Sci. Technol. 128:307-319. https://doi .org/10.1016/j.anifeedsci.2005.11.011.

Hristov, A. N., J. K. Ropp, K. L. Grandeen, S. Abedi, R. P. Etter, A. Melgar, and A. E. Foley. 2005. Effect of carbohydrate source on ammonia utilization in lactate dairy cows. J. Anim. Sci. 83:408421. https://doi.org/10.2527/2005.832408x.

Huntington, G. B. 1997. Starch utilization by ruminants: From basics to the bunk. J. Anim. Sci. 75:852-867. https://doi.org/10.2527/ $1997.753852 x$.

Kristensen, N. B., and D. L. Harmon. 2005. Effects of adding valerate, caproate, and heptanoate to ruminal buffers on splanchnic metabolism in steers under washed-rumen conditions. J. Anim. Sci 83:1899-1907. https://doi.org/10.2527/2005.8381899x.

Krizsan, S. J., S. Ahvenjärvi, H. Volden, and G. A. Broderick. 2010. Estimation of rumen outflow in dairy cows fed grass silage-based diets by use of reticular sampling as an alternative to sampling from the omasal canal. J. Dairy Sci. 93:1138-1147. https://doi .org $/ 10.3168 / \mathrm{jds} .2009-2661$.

Lee, M., R. Merry, D. Davies, J. Moorby, M. Humphreys, M. Theodorou, J. Macrae, and N. Scollan. 2003. Effect of increasing availability of water-soluble carbohydrates on in vitro rumen fermentation. Anim. Feed Sci. Technol. 104:59-70. https://doi.org/10.1016/ S0377-8401(02)00319-X.

Little, C. O., G. D. Potter, and G. E. Mitchell Jr. 1967. Rumen stimulatory factors in distillers feeds - Current developments. Pages 13-18 in Proc. Distillers Feed Conference, Cincinnati, OH.

Maeng, W. J., and R. L. Baldwin. 1976. Factors influencing rumen microbial growth rates and yields: Effects of urea and amino acids over time. J. Dairy Sci. 59:643-647. https://doi.org/10.3168/jds .S0022-0302(76)84253-1.

Marsetyo, M., J. V. Nolan, and C. J. Thwaites. 2005. The effect of molasses supplementation on rumen fermentation, microbial protein synthesis and nitrogen retention in sheep kept under high ambient temperature and fed urea-treated barley straw. Majalah Ilmiah Peternkan. 8. https://www.neliti.com/publications/164266/ the-effect-of-molasses-supplementation-on-rumen-fermentation -microbial-protein-s\#cite.

Mendoza, G. D., R. A. Britton, and R. A. Stock. 1993. Influence of ruminal protozoa on site and extent of starch digestion and rumi- 
nal fermentation. J. Anim. Sci. 71:1572-1578. https://doi.org/10 $.2527 / 1993.7161572 x$.

NRC (National Research Council). 2001. Nutrient Requirements of Dairy Cattle. 7th rev. ed. National Academies Press.

Nguyen, V. T., and T. R. Preston. 1999. Rumen environment and feed degradability in swamp buffaloes fed different supplements. Livest. Res. Rural Dev. 11:25.

Niederholtmeyer, H., B. T. Wolfstadter, D. F. Savage, P. A. Silver, and J. C. Way. 2010. Engineering cyanobacteria to synthesize and export hydrophilic products. Appl. Environ. Microbiol. 76:34623466. https://doi.org/10.1128/AEM.00202-10.

Nikodinovic-Runic, J., M. Guzik, S. T. Kenny, R. Babu, A. Werker, and K. E. O'Connor. 2013. Carbon-rich wastes as feedstocks for biodegradable polymer (polyhydroxyalkanoate) production using bacteria. Adv. Appl. Microbiol. 84:139-200. https://doi.org/10 .1016/B978-0-12-407673-0.00004-7.

Oba, M. 2011. Review: Effects of feeding sugars on productivity of lactating dairy cows. Can. J. Anim. Sci. 91:37-46. https://doi.org/ 10.4141/CJAS10069.

Penner, G. B., and M. Oba. 2009. Increasing dietary sugar concentration may improve dry matter intake, ruminal fermentation, and productivity of dairy cows in the postpartum phase of the transition period. J. Dairy Sci. 92:3341-3353. https://doi.org/10.3168/ jds.2008-1977.

Reynal, S. M., G. A. Broderick, and C. Bearzi. 2005. Comparison of four markers for quality microbial protein flow from the rumen of lactating dairy cows. J. Dairy Sci. 88:4065-4082. https://doi.org/ 10.3168/jds.S0022-0302(05)73091-5.

Ribeiro, C. V. D. M., S. K. R. Karnati, and M. L. Eastridge. 2005. Biohydrogenation of fatty acids and digestibility of fresh alfalfa or alfalfa hay plus sucrose in continuous culture. J. Dairy Sci. 88:4007-4017. https://doi.org/10.3168/jds.S0022-0302(05)73087 $-3$.

Roman-Garcia, Y., B. L. Denton, K. E. Mitchell, C. Lee, M. T. Socha, and J. L. Firkins. 2021. Conditions stimulating neutral detergent fiber degradation by dosing branched-chain volatile fatty acids. I: Comparison with branched-chain amino acids and forage source in ruminal batch cultures. J. Dairy Sci. 104:6739-6755. https://doi .org/10.3168/jds.2020-20054.

Ruiz-Moreno, M., E. Binversie, S. W. Fessenden, and M. D. Stern. 2015. Mitigation of in vitro hydrogen sulfide production using bismuth subsalicylate with and without monensin in beef feedlot diets. J. Anim. Sci. 93:5346-5354. https://doi.org/10.2527/jas.2015 -9392 .

Russell, J. B. 1998. The importance of $\mathrm{pH}$ in the regulation of ruminal acetate to propionate ratio and methane production in vitro. J. Dairy Sci. 81:3222-3230. https://doi.org/10.3168/jds.S0022 -0302(98)75886-2.

Russell, J. B., and D. B. Wilson. 1996. Why are ruminal cellulolytic bacteria unable to digest cellulose at a low pH? J. Dairy Sci. 79:1503-1509. https://doi.org/10.3168/jds.S0022-0302(96)76510 -4 .

Sannes, R. A., M. A. Messman, and D. B. Vagnoni. 2002. Form of rumen-degradable carbohydrate and nitrogen on microbial protein synthesis and protein efficiency of dairy cows. J. Dairy Sci. 85:900-908. https://doi.org/10.3168/jds.S0022-0302(02)74148-9.

Schingoethe, D. J., E. W. Skyberg, and R. W. Bailey. 1980. Digestibility, mineral balance, and rumen fermentation by steers of rations containing large amounts of lactose or dried whey. J. Dairy Sci. 63:762-774. https://doi.org/10.3168/jds.S0022-0302(80)83005-0.

Schlau, N., D. R. Mertens, K. Taysom, and D. Taysom. 2021. Technical note: Effects of filter bags on neutral detergent fiber recovery and fiber digestion in vitro. J. Dairy Sci. 104:1846-1854. https:// doi.org/10.3168/jds.2020-18731.

Shreve, B., N. Thiex, and M. Wolf. 2006. National Forage Testing Association (NFTA) method 2.1.4 - Dry matter by oven drying for $3 \mathrm{hr}$ at $105 \mathrm{C}$. National Forage Testing Association. Accessed Jan. 13, 2021. https://cfa.uaeu.ac.ae/en/doc/aridland/moisture analysis.pdf.

Sniffen, C. J., J. D. O'Connor, P. J. Van Soest, D. G. Fox, and J. B. Russell. 1992. A net carbohydrate and protein system for evaluating cattle diets: II. Carbohydrate and protein availability. J. Anim. Sci. 70:3562-3577. https://doi.org/10.2527/1992.70113562x.

Soder, K. J., A. F. Brito, and M. D. Rubano. 2013. Effect of supplementing orchardgrass herbage with a total mixed ration or flaxseed on fermentation profile and bacterial protein synthesis in continuous culture. J. Dairy Sci. 96:3228-3237. https://doi.org/10 .3168/jds.2012-6307.

Srinivas, B., and B. N. Gupta. 1997. Rumen fermentation, bacterial and total volatile fatty acid (TVFA) production rates in cattle fed on urea-molasses-mineral block licks supplement. Anim. Feed Sci. Technol. 65:275-286. https://doi.org/10.1016/S0377 -8401(96)01062-0.

Stone, W. C. 2004. Nutritional approaches to minimize subacute ruminal acidosis and laminitis in dairy cattle. J. Dairy Sci. 87:E13-E26. https://doi.org/10.3168/jds.S0022-0302(04)70057-0.

Sutton, J. D. 1968. The fermentation of soluble carbohydrates in rumen contents of cows fed diets containing a large proportion of hay Br. J. Nutr. 22:689-712. https://doi.org/10.1079/BJN19680080.

Vallimont, J. E., F. Bargo, T. W. Cassidy, N. D. Luchini, G. A. Broderick, and G. A. Varga. 2004. Effects of replacing dietary starch with sucrose on ruminal fermentation and nitrogen metabolism in continuous culture. J. Dairy Sci. 87:4221-4229. https://doi.org/10 .3168/jds.S0022-0302(04)73567-5.

Van Soest, P. J., J. B. Robertson, and B. A. Lewis. 1991. Methods for dietary fiber, neutral detergent fiber, and nonstarch polysaccharides in relation to animal nutrition. J. Dairy Sci. 74:3583-3597. https://doi.org/10.3168/jds.S0022-0302(91)78551-2.

Weisbjerg, M. R., T. Hvelplund, and B. M. Bibby. 1998. Hydrolysis and fermentation rate of glucose, sucrose and lactose in the rumen. Acta Agric. Scand. A Anim. Sci. 48:12-18. https://doi.org/ 10.1080/09064709809362398.

Weller, R. A., and A. F. Pilgrim. 1974. Passage of protozoa and volatile fatty acids from the rumen of the sheep and from a continuous in vitro fermentation system. Br. J. Nutr. 32:341-351. https://doi .org/10.1079/BJN19740087.

Wenner, B. A., E. Kesselring, L. Antal, T. Henthorne, and A. J. Carpenter. 2021. Dual-flow continuous culture fermentor system updated to decrease variance of estimates of digestibility of neutral detergent fiber. Appl. Anim. Sci. 37:445-450. https://doi.org/10 .15232/aas.2021-02144.

Zokaee, F., T. Kaghazchi, A. Zare, and M. Soleimani. 2002. Isomerization of lactose to lactulose-study and comparison of three catalytic systems. Process Biochem. 37:629-635. https://doi.org/10.1016/ S0032-9592(01)00251-5. 